\title{
Report
}

\section{The G8 Global Partnership against the Spread of Weapons and Materials of Mass Destruction}

\author{
CHARLES L. THORNTON
}

Charles L. Thornton is a doctoral candidate at the University of Maryland, where he is a graduate research fellow in the School of Public Affair's Center for International and Security Studies at Maryland. From 1994-2001, he provided on-site management support to the U.S. Department of Defense Cooperative Threat Reduction (CTR) Program as an employee of Science Applications International Corporation. ${ }^{1}$

$\mathrm{T}$ he Group of Eight (G8) leaders issued a statement from their summit in Kananaskis, Canada, on June 27,2002 , announcing a new initiative to formalize multilateral nonproliferation cooperation. ${ }^{2}$ According to the statement, the G8 nations will coordinate the funding and implementation of projects to prevent terrorists and other proliferators from acquiring nuclear, chemical, radiological, and biological weapons; missiles; and related materials, equipment, and technology. Intended initially to direct projects toward Russia, the G8 Statement leaves open the possibility of expanding similar efforts in the future to other Newly Independent States (NIS) of the former Soviet Union and possibly to other regions of proliferation concern. In the statement, the G8 nations committed up to $\$ 20$ billion to support such projects over the next 10 years.

Since 1991, the United States has sponsored the Nunn-Lugar threat reduction cooperation program to assist the NIS to dismantle their weapons of mass destruction (WMD); secure their WMD materials, technology, and expertise; and convert their WMD facilities to non- military purposes. ${ }^{3}$ While often considered a unique program with a limited scope, Nunn-Lugar has matured into a complex and comprehensive foreign policy and national security mechanism. Throughout the 1990s, the European Union (EU) — and to a lesser extent, Canada and Japanhas provided nonproliferation assistance to Eastern European and former Soviet states in parallel to the U.S. Nunn-Lugar programs. However, EU, Canadian, and Japanese efforts have historically been on a much smaller scale and largely directed toward the human and environmental aspects of the Russian WMD demilitarization effort. Moreover, the bilateral and multilateral agreements established by the EU member states, Canada, and Japan with Russia and the other NIS and Eastern European states largely lacked the rights and protections provided by the U.S.-NIS Nunn-Lugar agreements. In effect, therefore, the G8 Global Partnership rejuvenates and provides potential new funding sources from the other industrialized countries to expand and enhance the effectiveness of the Nunn-Lugar cooperative security model, whose benefits are recognized as universal by all involved. 
According to the U.S. State Department, the new G8 initiative was crafted in the environment following the events of September 11, 2001, when a consensus emerged that a terrorist group or outlaw state would be likely to use weapons of mass destruction if they possessed them. The United States did not pursue the partnership primarily as a burden-sharing initiative. Although the U.S. government clearly welcomes the prospects of increased nonproliferation funding from its G8 partners, the burden-sharing aspect of the initiative was not emphasized during the pre-summit negotiations. ${ }^{4}$ Nonetheless, Under Secretary of State for Arms Control and International Security John Bolton made it a point to note in his October 2002 testimony to a U.S. Senate Foreign Relations Committee hearing on the G8 Partnership that "The G7 members' [i.e., the G8 minus Russia] commitments should represent a fairer share of the responsibilities."

The G8 Statement provides six principles and nine guidelines intended to facilitate implementation of the nonproliferation assistance programs. All of the G7 countries have provided nonproliferation assistance to Russia in the past, and each has encountered implementation problems. Across the spectrum of problems the partners have encountered, the United States has met the fewest. Therefore, the specific language used in the statement draws largely from existing clauses in the U.S.-Russian Nunn-Lugar umbrella and implementing agreements. These provisions reflect, in this context, a desire on the part of the European, Canadian, and Japanese partners to obtain similar rights and protections.

For the partnership to be successful, it should ensure uniform application of the principles and guidelines. Moreover, if the partnership is to be considered an expansion of the U.S. Nunn-Lugar cooperative security model, the more successful projects are likely to be bilateral rather than multilateral, with solid coordination by the partnership's oversight body. This assertion is supported by past experience, where successful projects have been those in which one donor state found a discrete endeavor it could support that needed little multilateral coordination. In addition, the G8 can increase the effectiveness of the partnership by pushing for Russian Federal Assembly approval of the principles and guidelines in order to legitimize the program throughout the entire Russian government. Finally, U.S. leadership within the partnership should guide participants toward nonproliferation objectives not currently addressed by existing U.S. programs.

Efforts to implement the partnership have already begun. Russian Deputy Foreign Minister Georgy Mamedov met in August 2002 with Ambassador Linton Brooks, Acting Administrator of the U.S. National Nuclear Security Administration to discuss, among other topics, preparations for implementation of the G8 Partnership. The annual G8 cycle began in September 2002, and the nonproliferation partnership will be a major agenda item for 2002/2003. One effort within the first few months will be to organize the G8 Partnership's oversight body, to be known as the Nuclear Safety and Security Group (NSSG).

This report reviews the general and specific issues surrounding the G8 Global Partnership. The first section provides an overview of the partnership's goals and intentions. The report then reviews Russian reaction to the G8 Statement. It also discusses past experiences with multilateral threat reduction efforts and assesses the lessons that can be drawn from the U.S. Nunn-Lugar programs. The report analyzes several major issues that will impact the implementation of the G8 Partnership and reviews selected clauses of the G8 Statement. The report concludes with some final observations, including recommendations that would enhance the partnership's opportunities for success.

\section{Overview of the G8 Partnership}

Some are calling the G8 Partnership a "10 plus 10 over 10 " agreement, referring to $\$ 10$ billion from the international community, plus $\$ 10$ billion in already-planned U.S. funding, over the next 10 years. The statement does not commit Russia to any internationally accountable funding. Some observers and Nunn-Lugar managers were optimistic initially that this new initiative from the G8 would bring more U.S. funding for current programs and provide some impetus for an expansion into new areas, or areas discussed previously with Russia but rejected. In reality, the United States did not commit to any additional funding beyond its current plans. The G8 Statement itself says, "All funds disbursed or released after its announcement would be included in the total of committed resources." In fact, both unobligated and planned funding will count toward the U.S. contribution. If the United States maintains currently planned funding levels_-about $\$ 1$ billion annually_-it will fulfill its G8 commitment without any adjustments. Presuming that the U.S. sets its annual funding allocation at the $\$ 1$ billion target, and presuming that — as many analysts assert — the proliferation threat stemming from the NIS has not been sufficiently addressed, the promise of increased funding 


\section{TABLE 1}

\section{G8 Funding Commitments to Date}

\begin{tabular}{lc}
\hline Recipient & $\begin{array}{c}\text { Billions of U.S. } \\
\text { Dollars }\end{array}$ \\
United States & 10 \\
\hline Canada & 0.65 \\
\hline United Kingdom & 0.75 \\
\hline Germany & 1.5 \\
\hline European Commission & 1 \\
\hline Japan (initially) & 0.2 \\
\hline ltaly* & 0.4 \\
\hline Other pledges not yet publicly announced \\
\hline Total & $15+$ \\
\hline
\end{tabular}

Sources: Except where noted, U.S. Department of State, Testimony of Under Secretary Bolton to the Senate Foreign Relations Committee, October 9, 2002; where noted by (*), Russian American Nuclear Security Advisory Council, Testimony of Executive Director Kenneth Luongo to the Senate Foreign Relations Committee, October 9, 2002.

contributions from the European, Canadian, and Japanese Partners offers an opportunity to enhance and even accelerate realization of important nonproliferation objectives.

Those who drafted the G8 Statement drew heavily on the existing U.S.-NIS Nunn-Lugar agreements. The G8 Statement contains a detailed list of principles and guidelines that extend many of the protective clauses found in the Nunn-Lugar agreements to the broader G8 community. The G8 partners deliberately constructed the guidelines to address not only the more contentious implementation issues encountered by the U.S.-Russian experience, but also to reflect the many bilateral experiences of the other G8 countries in executing cooperative agreements for preventing proliferation.

Each G8 Partner has its own set of national priorities. Moreover, most of the partners have projects either ongoing or under discussion. The European partners, in particular, were not waiting for the G8 agreement and would have moved ahead with existing or planned nonproliferation assistance programs. However, according to the U.S. State Department, these projects would likely have been modest in comparison to the scope of the new G8 Partnership. ${ }^{?}$

The guidelines include clauses providing participants with the right to monitor and audit activities, exemption from taxes and duties, protection against liability claims, and privileges and immunities for donors. Several phrases applied in the statement, such as "monitoring," "transparency measures," and "adequate access for donor repre- sentatives to work sites" are clearly intended to fill the holes that have caused problems with the existing U.S. Nunn-Lugar programs.

\section{Russian REACTIONS}

At the outset of negotiations within the G8, Russia was not enthusiastic about the proposed nonproliferation initiative. The Russian government viewed the language in the proposed G8 Statement to be constraining. However, due to a strong desire on the part of Russian President Vladimir Putin, the financial incentives promised by the partnership, and the logic of the G7 argument, the Russian government came to understand through many negotiating cycles that the partners were not asking for any new concessions. Rather, the intention of the G8 Statement is to ensure uniformity for both donors and recipients. ${ }^{8}$

Reactions from Russian officials to the G8 Partnership have been mixed. On the one side, many opposition figures are leveling the same criticisms at the initiative as have been heard in the past regarding Nunn-Lugar. For example, General (Retired) Leonid Ivashov, a former Russian General Staff officer well-known for his skepticism about Western motives, stated, "Russia is invited to join, but we are treated like a beneficiary not as an equal." Gennady Zyuganov, the leader of the Russian Communist Party, asserted, "It is clear that the billions of dollars to be allocated to Russia by Western countries are designed to completely annihilate Russia's nuclear missile shield." Political figures closer to the current Russian government, however, see a benefit to internationalizing the current nonproliferation and threat reduction programs. Alexei Arbatov, a prominent member of the Russian Duma, indicated that this program would help Russia to focus more of its attention on Europe and away from the United States, thus limiting what some Russians view as an increasingly U.S.-dominated, unipolar world. ${ }^{9}$

\section{Past Experiences with Multilateral Cooperation}

The G8 Statement calls for extensive multilateral cooperation with phrases such as "mutually agreed effective monitoring," "G8 will work in partnership, bilaterally and multilaterally," and "bilateral and multilateral project implementation will be coordinated." Past experience, however, raises some concerns on several levels: overall coordination, unintended side effects of programs, and Russian priorities and concerns. 
Of course, there have been some successes with multilateral cooperation. Two of the primary reasons the G8 codified this new partnership was to give wider applicability to many of the protections afforded to the United States in its Nunn-Lugar umbrella agreement with Russia, and to build on those past successes. Examples of how these concerns manifested themselves in the past and measures that may be taken to mitigate these concerns in the future are elaborated in the following sections.

\section{Prior NATO Coordination Efforts}

In the mid-1990s, several European countries started to provide nuclear safety and security assistance to the NIS. At the international level, the Europeans coordinated their assistance through two fora: the North Atlantic Treaty Organization (NATO) and the EU. NATO's involvement did not extend much beyond gathering information from donor states and generating top-level spreadsheets to track the assistance. Although NATO discontinued its coordination effort after a couple of years, the donors did gain experience working to coordinate their assistance efforts.

European assistance tracked by NATO included emergency response equipment, nuclear warhead transportation security, defense conversion activities, fissile material control assistance, and retiring military officer assistance (such as housing and retraining). Although Germany provided substantial funding to move Soviet officers out of the former East Germany, most European projects were minor and restricted to limited, discrete objectives.

\section{Prior European Union Coordination Efforts}

The EU internal coordination effort, however, has been more formal and more extensive than the NATO endeavor. On December 17, 1999, the EU established a Cooperation Program for Non-Proliferation and Disarmament in the Russian Federation, within the framework of the EU's Common Foreign and Security Policy. ${ }^{10}$ Under that action, the EU allocated 8.9 million euros ( $\$ 8.8$ million) for a set of studies on plutonium transport, storage, and disposition, and for initial support to a chemical weapons pilot destruction plant situated in Gorny, Saratov Oblast. The EU plan would suspend the program if the Russian Federation failed to cooperate fully with the implementation of the program, or failed to allow EU monitoring and/or periodic external evaluations and audits.

Most European contributions to multilateral efforts in the nuclear safety area are channeled through the EU
Technical Assistance for the Commonwealth of Independent States (TACIS) nuclear safety programs. TACIS is the EU assistance program to the partner states in Eastern Europe and Central Asia. Through transfer of knowhow, TACIS aims at assisting the partner countries in their reform process to market economy and democracy, primarily through grant assistance. According to the TACIS Information Center, since its launch in 1991 through the end of 1999, the program has committed some 6 billion euros ( $\$ 5.9$ billon). The European Commission, however, reports that of that total amount, only 155 million euros ( $\$ 154$ million) in TACIS funding was allocated to Russia for nuclear safety efforts between 1997 and 2001, with a total of approximately 300 million euros ( $\$ 298$ million) allocated between 1991 and 2001. ${ }^{11}$ For 2000-2006, 3.1 billion euros ( $\$ 3$ billion) have been allocated. As one European analyst observed, the objectives of this period are "based on an understanding that cooperation is a reciprocal process. Tendencies are toward increased cooperation and more coordination with other donors. This should provide an opening for increased coordination with U.S. support to Russian nuclear disarmament."12

To further support Russia's pursuit of a safe and environmentally sound dismantlement or reconversion of infrastructure, equipment, and scientific capabilities linked to weapons of mass destruction, the EU decided in 2001 to provide 6.08 million euros ( $\$ 6.04$ million) to fund several project areas. ${ }^{13}$ According to a Council Decision of June 25, 2001, implementing Joint Action 1999/878/ CFSP with a view to contributing to the European Union

\section{TABLE 2 \\ European Union Contributions for the 10-Year Period 1992-2001}

\begin{tabular}{lr} 
Program & Millions of Euros \\
Nuclear Weapons Destruction & 309 \\
\hline Stabilization/Re-conversion of Experts & 115 \\
\hline Chemical Weapons Destruction & 88 \\
\hline Control of Nonproliferation & 34 \\
\hline Re-conversion of Facilities & 4 \\
\hline Total & 550 \\
\hline
\end{tabular}

Source : European Commission; IP/01/329 - Brussels, March 7, 2001 


\section{TABLE 3}

\section{TACIS Funds Allocations to Russia for Nuclear} SAFETY

\begin{tabular}{lc}
\hline Year & Millions of Euros \\
& \\
\hline 1997 & 34 \\
\hline 1998 & 17 \\
\hline 1999 & 12 \\
\hline 2000 & 33 \\
\hline 2001 & 19 \\
\hline Total & 115 \\
\hline
\end{tabular}

Source : European Commission

Cooperation Programme for Non-Proliferation and Disarmament in the Russian Federation (2001/493/CFSP), the EU plans to provide: ${ }^{14}$

- Support to the Russian Nuclear Safety Authority (Gosatomnadzor) for developing the regulatory basis and documents for the disposition of weapons-grade plutonium

- Support for studies and experimental studies for mixed oxides fuel (MOX) demonstration and licensing

- A cooperative feasibility study for immobilization of Russian waste containing weapons-grade plutonium

- Support to the Russian Ammunition Agency (RMA) to fulfill the Russian Federation's responsibilities under the Chemical Weapons Convention (CWC)

- Support for infrastructure building related to the destruction of nerve gases stored at the Shchuchye site.

The last point is discussed in greater detail below. It is interesting to note here, though, that much of the EU assistance program for Russian CW destruction is designed around project areas in which the U.S. is precluded by law from participating. The U.S. Congress, moreover, has precluded all Nunn-Lugar programs from providing infrastructure-building support, contending that such activities are peripheral to the central U.S. national security objective and should be provided by the recipient government-Russia in this case. Ongoing and augmented EU support to the Shchuchye CW destruction site, in fact, was largely in response to the suspension of funding from the U.S. by Congress in 1999. Thus, as discussed further elsewhere in this report, multilateral nonproliferation cooperation had already been taking place long before the G8 established a formal process.

\section{Prior Group of Seven Coordination}

Coordination through the G8 (known as the G7 before Russia's accession) is not without precedent. Largely in response to the 1986 Chernobyl disaster, the G7 initiated a program of multilateral nuclear safety assistance at its 1992 Munich Summit. Since then, European multilateral and bilateral assistance has focused on technical upgrades and advice, improvements in reactor operations and emergency procedures, and enhancement of regulatory regimes.

At a 1996 G7+1 Nuclear Safety and Security Summit, the participants agreed that, "National efforts have been made in the countries of Central and Eastern Europe and the Newly Independent States to improve nuclear safety levels, often in cooperation with multilateral and bilateral programmes [sic]. In this regard, we acknowledge these important efforts to upgrade reactor safety and improve safety culture, but note that further substantial progress is still required. We reaffirm our commitment to cooperate fully for this purpose."15 During this session, the $\mathrm{G} 7$ acknowledged the cooperative programs of Canada, France, Germany, Italy, Japan, the United Kingdom (U.K.), and the United States with Russia for the safe storage and the peaceful uses of fissile material released by the dismantlement of nuclear weapons, and their safe and secure transportation for that purpose. The 1996 Summit, held in Moscow, was intended to coordinate the national activities and priorities of the $\mathrm{G} 7+1$ states in the area of peaceful uses of nuclear energy. The participants agreed on a framework of general goals and objectives covering a range of nuclear energy-related topics, including the safety of civilian nuclear reactors; nuclear liability; energy sector strategies in transition countries; nuclear waste management; ocean dumping; nuclear material safety; illicit trafficking in nuclear material; nuclear material accounting, control, and physical protection; and safe and effective management of fissile material designated as no longer required for defense purposes.

Britain's Department of Trade and Industry (DTI), for example, coordinates U.K. policies and activities in this area and manages U.K. contributions to international assistance programs. Currently, DTI is responsible for managing a new three-year, 85 million pound (\$132 million) program of assistance to address the wide range of 
nuclear safety and security problems faced by the states of the NIS. The U.K. has also contributed 18.25 million pounds ( $\$ 28.32$ million) to the Nuclear Safety Account, managed by the European Bank for Reconstruction and Development, which funds short-term plant safety upgrades at some of the earliest Soviet design reactors still in operation.

As opposed to the approximately $\$ 7$ billion allocated to Nunn-Lugar by the United States since 1992, the remaining G7 members have provided in total less than $\$ 1$ billion. Although many donor countries have been willing to allocate additional nonproliferation funding, some have been unable to establish acceptable government-to-government implementing agreements that would provide liability protections, tax exemptions, and transparency measures. As U.S. Under Secretary of State Bolton stated, "Millions of dollars previously committed by G8 members remain unexpended at present due to these problems, and G8 members will have difficulty committing new funds if these difficulties persist." 16

\section{Case Studies from the U.S. Cooperative Threat Reduction Experience}

Since 1991, the U.S. Nunn-Lugar program has matured from a relatively modest program managed by a single U.S. government agency to a complex effort managed by multiple U.S. government agencies working in cooperation with a multitude of foreign government agencies in each of several countries throughout the NIS. This growth has been an evolutionary process, as the U.S. Departments of Commerce, Energy, State, and others have assumed direct authority and appropriations for projects once managed by the Department of Defense (DoD). Many of the lessons to be learned from these experiences, including internal coordination problems, openness and access issues, and taxation and liability challenges were directly addressed by the G8 Statement. There are additional lessons from prior U.S. attempts at coordination with its European, Canadian, and Japanese partners that should be considered as the G8 implements the global nonproliferation partnership. Described below are several cases from DoD's Cooperative Threat Reduction (CTR) program.

\section{Emergency Response}

Despite the unqualified success of some projects, others failed to produce positive results because of such problems as the lack of interoperability of equipment. For example, in the mid-1990s, a U.S. CTR team conducted an audit and examination of emergency response (ER) equipment provided to the Russian Ministry of Atomic Energy (Minatom). While checking the equipment in a warehouse outside of Moscow, the Minatom escort offered to show the DoD team similar equipment provided by several European donors. The Minatom escort opened several doors around the central warehouse holding area to reveal ER equipment from Germany, Italy, and Britain. Although it was all viable equipment, none of it was interoperable. The Minatom escort correctly observed that it is expensive and inefficient to train troops to use four different types of protective clothing, for example, so much of the equipment went unused.

History may already be repeating itself. In 2002 prior to the G8 Summit, several NATO countries approached Russia with offers of assistance. Russia returned a request for emergency response equipment, perhaps because such equipment would be relatively simple to negotiate and would require few, if any, intrusive audit measures by the NATO donors. A U.S. government official knowledgeable of the historical experiences described above is consulting with the involved NATO partners, and has expressed concerns similar to those outlined here.

\section{Mayak Fissile Material Storage Facility}

Another example from the U.S. Nunn-Lugar experience demonstrates the difficulty in attempting to coordinate complex construction projects on a multilateral level. In the mid-1990s, Japan approached the United States with its desire to provide $\$ 30$ million of threat reduction assistance to Russia. Japan did not want its assistance to conflict with ongoing U.S. programs, so it asked the United States to help coordinate its contribution. The United States suggested that Japanese funding could best support the Mayak Fissile Material Storage Facility, which will store plutonium removed from dismantled nuclear weapons. The two donors approached Minatom with this proposal. Minatom listened to the Japanese offer, but did not propose a particular section of the Mayak building that could be designated as Japan's contribution. Instead, Minatom raised some objections to Japanese participation in the Mayak project, citing technical coordination issues and concerns about Japan's status as a non-nuclear weapon state. There may also have been other extenuating reasons behind the Russian stance. In any event, after three to four years of negotiations, the proposed Japanese funding went unspent. 


\section{Shchuchye Chemical Weapons Destruction Facility}

One CTR program with significant experience in building multilateral cooperative assistance is the Chemical Weapons Destruction Facility (CWDF) at Shchuchye. CTR program managers have expended considerable efforts in the major European capitals generating support for the CWDF. In particular, DoD envisions international contributions not only for the design and construction of the facility, but also the Russian-mandated social infrastructure-which Russia has struggled to provide and which the United States is precluded from funding by law. Although the Bush administration's strategic review of threat reduction programs, conducted by the National Security Council (NSC) in 2001, recommended accelerated implementation of the CWDF, Congressional support has been problematic. This is because many in the U.S. Congress have viewed the CW problem as a local Russian environmental problem and not a strategic threat to the United States. ${ }^{17}$ Without U.S. leadership, the Europeans appear unwilling to forge ahead. This is confirmed to some extent by the EU documents cited elsewhere in this report, which defer heavily to U.S. Congressional funding constraints and U.S. administration implementation decisions.

To date, eleven countries, including the United States, have either provided CWDF assistance, have allocated funding to do so, or are considering such provisions. Italy is constructing a gas pipeline, Canada and the United Kingdom are helping with the design and construction of power supply systems, and Norway is providing facility construction assistance. The European Union, Germany, Switzerland, Sweden, Finland, and the Netherlands are also contributing to $\mathrm{CW}$ destruction in Russia.

Approximately 90 percent of the funding needed to construct the Shchuchye facility is slated to come from the United States, with the remainder from the states listed above and Russia itself. In 1999, however, Congress froze U.S. participation in the program based on concerns that the CWDF would not be able to meet its objectives. Russia met many of the conditions set by Congress, and U.S. assistance has subsequently resumed. ${ }^{18}$ While the CWDF has yet to be built, and the proposed facility's CW destruction capacity remains contentious, the effort that has gone into multilateralizing the project might serve as an example for the G8. That is, although the donor states have combined their resources to construct a single facility, each has found a niche aspect to which it can contrib- ute and independently manage. Furthermore, the lessons learned through the initial efforts to coordinate among the donor states should provide valuable insights for the G8 Partnership. The Russian Munitions Agency itself states that, "The statement of the leaders of G8 on global partnership against spread of armament and materials of mass destruction, made in Kananaskis, undoubtedly will give the novel impulse to the chemical disarmament. This historic statement signifies a new stage, the outstanding feature of which is the awareness by the world community, that the quickest disposal of chemical weapons is a general objective."19

\section{Moscow and Kiev Science and Technology Centers}

Another example of multilateral cooperation is the science and technology center model-the International Science and Technology Center (ISTC) ${ }^{20}$ in Russia and the Science and Technology Center in Ukraine (STCU). ${ }^{21}$ Established in 1992 and 1993, respectively, both centers administer collective efforts by member states to engage weapons scientists throughout the NIS. Managed on the U.S. side by the State Department, donor participants include the United States, the European Union, Japan, Canada, Sweden, Norway, and the Republic of Korea. A governing board at each center, consisting of member representatives, builds consensus approval for funding activities, but members also retain broad national discretion in project funding and other programmatic decisions, according to the State Department.

Between 1993 and 2000, EU support to science and technology cooperation has amounted to about 185 million euros ( $\$ 183$ million), enabling some 45,000 Russian scientists to be involved in EU-funded programs. According to the European Commission, TACIS has contributed about 100 million euros ( $\$ 99.7$ million), mostly through the ISTC. The EU reached a Science and Technology Agreement with Russia in May 2001 to improve the access of Russian scientists to European programs and ensure EU scientists a reciprocal access to Russian research projects. Technical assistance will support the commercialization of Russian research results and the development of related small- and medium-sized businesses.

The centers' long-term goals are to redirect weapon science expertise away from WMD activities and toward commercial endeavors. These endeavors are designed to support transitions to market economies, create partnerships with foreign industries, and integrate scientists into 
the international community. While critics question the success of the program, the science and technology center model may serve as a starting point for collaborative G8 Partnership endeavors.

Like the CWDF project described above, and the broader Nunn-Lugar and other foreign nonproliferation assistance programs in Russia, the ISTC has encountered many political and bureaucratic problems. ${ }^{22}$ Common themes include the lack of Russian Federal Assembly ratification of the ISTC agreement, tax exemption problems, accusations from Russia that the project aimed to buy Russian knowledge and technology at below market prices, and customs difficulties. Since project proposals must be reviewed by a multilateral government body, the ISTC/STCU model has been further criticized for taking too long to issue decisions on grant applications. Perhaps most serious are accusations that ISTC/STCU funding allows scientists to continue with their weapons-related activities while fulfilling their commercial contracts. ${ }^{23}$

Nonetheless, the centers have engaged tens of thousands of former weapons scientists in a wide range of scientific areas. Just as valuable lessons were learned during the CWDF international coordination process, the experiences gained from creating, managing, and sustaining a multilateral governing body-one that is expected to address the national priorities of several member statesshould be useful as the G8 embarks on its new initiative.

\section{Major Issues That Will Impact G8 Partnership Implementation}

Based on more than a decade of experience, the United States and its G8 partners have encountered a number of issues that have affected implementation of the international nonproliferation programs. The G8 nonproliferation partnership will need to address these issues if its efforts are to prove successful.

\section{Access/Transparency}

Perhaps the single most influential determinant of success for previous and existing U.S. Nunn-Lugar projects in Russia is transparency, sometimes referred to as access or openness. One of the immutable realities of the international nonproliferation assistance programs is their onesided nature: Donors require transparency into the work they are funding in order to assure their taxpayers that the funds are used for their intended purposes. Unlike formal, negotiated arms control agreements, there are no built-in provisions for mutual, reciprocal inspections. It is unclear to what extent the absence of formal reciprocal access requirements has affected Russia's reluctance to grant foreign visits to its sensitive sites. Many analysts have warned that donor states should not seek to buy access through assistance programs, and that openness on a reciprocal basis is the only equitable solution. The offer of informal visits of Russian experts to sensitive facilities in the G7 Partner countries might help to placate Russian apprehension on this issue.

Of course, when transparency is a non-issue, or when access is routine and reliable, there is little question of Nunn-Lugar's effectiveness. For example, these concerns are non-issues when the U.S. is procuring equipment outside of Russia or at joint centers such as the ISTC. Moreover, access to sites considered sensitive has become routine under DoD CTR's Strategic Offensive Arms Elimination (SOAE) program. SOAE benefits from the foreign access legalized by the ratification of the 1991 Strategic Arms Reduction Treaty (START) I. However, for programs where the United States has had little or no access to the work sites, or where the exchange of sensitive information has been problematic, the assistance efforts have met with considerably less success. This has been the case for the U.S. Department of Energy's (DOE's) attempts to provide warhead dismantlement assistance to Minatom and DoD's attempts to provide nuclear warhead security assistance at Russian Ministry of Defense (MOD) storage sites.

An important aspect of Russian bureaucratic reluctance to grant access to sensitive facilities may be the political risks incurred by senior ministerial officials and facility managers. That is, those who are in charge of the facilities may be concerned that, once foreign access is granted, political sentiments might change and they would be left unprotected. Therefore, it is crucial that top levels of the Russian government - the president and the prime minister, specifically_guarantee the political cover of those authorized to grant foreign access. This scenario, in fact, appears to have opened the door for DoD to begin implementing security enhancements at Russian MOD nuclear weapon storage facilities.

On May 24, 2002, the United States and Russia entered into the Strategic Offensive Reductions Treaty (also known as the Moscow Treaty). ${ }^{24}$ It limits the parties to the deployment of 1,700-2,200 nuclear warheads by December 31, 2012. Unlike the Moscow Treaty's predecessors, however, it does not include extensive verification measures and transparency protocols. Although comprehensive warhead inventory accounting provi- 
sions - including weapons both deployed and in storage and fissile material removed from warheads-were envisioned by previous presidential summit declarations, this most recent treaty will rely for the time being on the verification regime established by START I.

Many arms control proponents consider the Moscow Treaty to be a lost opportunity. That is, it neither provided the means for conducting mutual and reciprocal comprehensive warhead and fissile material inventory accounting, nor did it address short-range, or tactical nuclear weapons. Although the G8 Global Partnership cannot provide the strategic stability foundation of mutual reciprocal inspections, it has the potential to fill at least part of that void. U.S. Senator Richard Lugar explained this potential role as follows:

Through the Nunn-Lugar program, the United States could maintain a window of observation into Russian dismantlement, as well as serve as a venue to provide Russia with an understanding and view of American reductions. It would not be capable of completely replacing a treaty verification regime, but it would be tremendously valuable tool. In addition to the utilization of national technical means, Pentagon contract inspection and acceptance visits as well as audit and examination visits could provide an effective verification tool. Anyone who has witnessed the contractual negotiating process involved in undertaking and implementing a Nunn-Lugar project as well as the role of American firms in managing such projects on site and the auditing practices to ensure proper utilization of U.S. funds, can attest that the inspection and verification procedures associated with the program are every bit as stringent and intrusive as similar measures under an arms control regime..$^{25}$

As pointed out earlier, this line of argument does not address Russia's concerns over mutuality and reciprocity. It also lends further credence to arguments from Russia that Western donors are simply trying to purchase access to Russia's most sensitive facilities. Although it is unlikely that the United States or any of the other G7 donor states would be willing to build formal inspections of their own facilities into the threat reduction cooperation agreements-and it does not seem appropriate either-there may be one exception. Traditionally, the military-tomilitary contacts element of the DoD CTR program has been allocated to the U.S. military regional and functional commanders-in-chief, allowing them to fund exchange programs with NIS counterparts. This may be a venue through which senior Russian officials could visit U.S. installations and observe operations related to the dis- mantling of WMD in the guise of a confidence building measure. In any case, an effective partnership with Russia must be predicated on transparency in both directions.

\section{Taxation}

Guideline V includes a promising feature of the G8 Statement. One fundamental reason why the tax issue continues to plague the U.S.-Russia threat reduction programs is that, after the Russian Federation signed the original Nunn-Lugar umbrella agreement in 1992, the Russian Duma passed a law requiring agreements that addressed taxation be approved by the legislature. This provided an opening for Russian agencies with taxation authority to try to tax U.S. dismantlement and nonproliferation assistance. When Russian federal, regional, and local agencies become involved in the activities of the U.S. Nunn-Lugar programs, they do not feel bound or compelled by the umbrella and implementing agreements, and are therefore often unwilling to step outside their standard bureaucratic operating procedures.

The following is a partial list of typical problems caused by the taxation issue:

- Donor equipment is delayed in Russian entry ports when the shippers claim exemption from customs duties.

- United States firms seeking to conduct business operations in Russia are denied permits when they claim tax exemptions.

- Russian firms are unable to fulfill contracted or subcontracted work when they claim exemption from paying income taxes.

These problems routinely cause project implementation delays, often for months. The U.S. Embassy in Moscow issues pro forma tax exemption support letters to CTR contractors, but the letters may be ignored, or the Russian agency in question may take its time confirming the letters' legitimacy.

Contractors, U.S. Embassy attorneys, and NunnLugar policy officials have met often with the various Russian agencies, and in particular, the Russian Tax Inspectorate. The basis of the Tax Inspectorate's consistent denial that the tax exemption claimed under the umbrella agreement was valid is that the original umbrella agreement was never submitted for Federal Assembly consent. As a government-to-government joint threat reduction program, Nunn-Lugar was never intended to function as a treaty. The sides were expected to conduct the threat reduction activities in an environment of cooperation. It 
was not until the United States and Russia signed the protocols in 1999, which included additional clauses for taxation and other provisions, did Russia submit the umbrella agreement to the Federal Assembly for concurrence. As a result, as described below, there has been some recent progress on this issue.

\section{Debt for Nonproliferation}

One idea that has become increasingly popular in recent years, particularly in the U.S. Congress, would exchange Russia's foreign financial debt for a concurrent and equivalent Russian nonproliferation budget increase. This notion has proponents in Europe and Japan as well as the United States, and is likely to pick up momentum given U.S. leadership. In fact, the Kananaskis G8 Statement directly references the debt-for-nonproliferation program option as one method donors may use to fulfill their funding commitments.

On September 30, 2002, President Bush signed into law the Russian Federation Debt Reduction for Nonproliferation Act of 2002. This act establishes "debt for nonproliferation swaps" and is modeled on past successful debt reductions for environmental protection efforts. Through the swaps, the U.S. Treasury Department would restructure part of Russia's debt to the United States. In exchange, Russia would further its work on joint nonproliferation programs that safeguard Russian nuclear materials, maintain effective export controls, dismantle Russian nuclear facilities, and help unemployed nuclear scientists find work other than with nations and terrorist organizations seeking to build their own nuclear arsenals. ${ }^{26}$

In 2003, Russia will confront a large increase in interest payments on its foreign debt. According to a draft federal budget submitted to the Duma, Russia's foreign state debt is expected to be $\$ 124.5$ billion, including a debt of $\$ 52.7$ billion to foreign governments. The Russian Finance Ministry reported that foreign debt payments would reach $\$ 17.3$ billion by 2003. In 2001, Russia attempted to reschedule billions of dollars of foreign debt, but the negotiations failed, and Russia went ahead with the required payments. Germany is Russia's major creditor, with Russian debt to Germany totaling $\$ 18.6$ billion. As of January 1, 2003, Russia will owe $\$ 5.5$ billion to Italy, $\$ 3.8$ billion to the United States, $\$ 3.7$ billion to Japan, $\$ 3$ billion to France, $\$ 1.7$ billion to Canada, $\$ 2.6$ billion to Austria, and $\$ 1.4$ billion to Britain. Russia's other creditors include Australia, Belgium, Denmark, Spain, the Netherlands, Norway, Portugal, Finland, Switzerland, and Sweden. ${ }^{27}$
However, Russians have expressed some concern about a debt swap scheme. They worry that any debt forgiveness, as it appears to creditors, may have an adverse affect on Russia's international credit rating. The Russian Finance Ministry would become involved in any debt swap discussions and may ultimately prefer to pay its debt rather than receive debt reduction in order to shift funding into nonproliferation activities. It appears that Russia will be able to pay these debts, assuming it reaches its third consecutive surplus budget as planned. The budget anticipates revenues to top about 2.4 trillion rubles ( $\$ 75$ billion) and expenditures of approximately 2.3 trillion rubles ( $\$ 72$ billion). ${ }^{28}$ "If Russia manages to pass the peak, confidence in our country will grow a lot," Deputy Finance Minister Kudrin said, according to ITAR-TASS news agency. ${ }^{29}$

Some analysts in the U.S. believe that a debt-fornonproliferation program would provide a new source of funding for Russian WMD threat reduction. In fact, it may result in a net loss of funding. First, the Bush administration and the U.S. Congress are likely to view the $\$ 1$ billionper-year commitment under the G8 Partnership as an overall marker for budget planning. Given that the U.S. has already budgeted this amount for NIS threat reduction, any debt forgiven may require an equivalent budget reduction. For example, if Russia pledged to increase funding for fissile material security in exchange for an equivalent U.S. debt reduction, Congress might reduce DOE's budget in that area. At this point, the details have not been worked out and these concerns are speculative. However, it is likely that many European countries, Canada, and Japan will consider seriously the debt swap program and count it toward their G8 Partnership contribution. In any case, there is no universal consensus on pursuing debt for nonproliferation, and any such initiatives will be based on national decisions.

\section{Unaddressed Proliferation Threats}

Perhaps the most promising aspect of this new initiative is the possibility of providing assistance in areas that the United States is unwilling or unable to pursue. For example, during one NSC meeting held in Spring 2001 as part of the Bush administration's "strategic review," a Russian proposal to fund the dismantlement of general purpose, nuclear-powered submarines was rejected. These submarines, despite being nuclear powered, were essentially considered a local Russian environmental problem and not a strategic proliferation threat. This NSC decision was never fully publicized, and the idea remained 
important to the non-governmental, European, and Russian disarmament and nonproliferation communities. It has now resurfaced in the G8 forum, obviously with U.S. acceptance and perhaps with the hope that another G8 country would take up the effort. ${ }^{30}$

As another example, the G8 Statement calls for the partners to "develop and maintain appropriate effective measures to account for and secure [WMD weapons and materials]." One way to read this clause is that it is Russia's responsibility alone to develop and maintain the accounting. Given the context of this partnership, however, one could interpret the clause to mean that there will be bi- or multi-lateral measures developed. With the signing of the Moscow Treaty, the United States and Russia appear to have further postponed the resolution of long contentious issues regarding transparency of warhead stockpiles. By leveraging the multilateral aspect of the G8 Partnership, however, the participation of the G8 partners in these discussions may allow a more comprehensive approach to such issues.

\section{Russian Domestic Law}

It has become apparent that the only long-term solution to the transparency, taxation, and liability issues is a legal one. The Russian government, preferably through the passage of legislation in the Russian Federal Assembly, should legitimize the threat reduction guidelines and principles so that they carry the weight of domestic law. Although a presidential decree does not carry the same weight as legislative approval, it has been used effectively in the past to establish national policy at least as an interim measure. In either case, the legal authority should be applicable at the federal, regional, and local levels. The Russian government is currently seeking Federal Assembly approval of the 1999 Protocols to the U.S.-Russian Nunn-Lugar umbrella agreement. Bilateral or multilateral agreements for threat reduction efforts under the G8 Partnership would probably also benefit from endorsement by the Russian Federal Assembly.

As a G8 leader, Russian President Putin will be expected to comply with the statement's content, and therefore may be obligated to implement it in Russia. One might speculate, therefore, that much of the statement may be designed to either (1) provide President Putin with internationally agreed language that helps him acquire legislative endorsement from the Federal Assembly, perhaps through ratification of international agreements, or (2) to encourage him to issue a presidential decree that carries sufficient legal weight. As U.S. Under Secretary
Bolton told the U.S. Senate Committee on Foreign Relations in October 2002: "For the new Global Partnership to be successful, the Russian Federation will need to take concrete actions to resolve outstanding problems." ${ }^{1}$

For Russia's Federal Assembly to consider seriously ratification of new nonproliferation agreements, it may require that two conditions be satisfied. First, the promise of substantial new funding would facilitate acceptance of the guidelines and principles established by the G8 Statement. It appears that this possibility may come to fruition if the Canadian, European, and Japanese partners can establish acceptable bilateral implementing agreements. Second, the lack of reciprocity in terms of transparency may hinder Federal Assembly approval. The simple virtue of nonproliferation is unlikely to sway even the most altruistic Russian legislator if it means that Western nations will gain asymmetric access to sensitive Russian facilities. It will be incumbent on the donor states, therefore, to establish a broader framework under which Russia obtains the necessary reassurances to allow the program to move forward.

\section{Russian Funding and Absorption Capacities}

The U.S. Nunn-Lugar program is partially designed around Russia's ability to fund its own dismantlement and WMD security efforts and its ability to absorb infusions of donated equipment and services. There is growing evidence that Russia deliberately structures its annual federal budget in the areas of demilitarization, arms dismantlement, and proliferation prevention around expectations of foreign assistance. Russia obviously contributes considerable resources in the form of labor, wages, facilities, real estate, equipment, training, and operations and maintenance. In the area of CW destruction, in fact, Russia has greatly increased its budget allotments for the Shchuchye site in order to meet U.S. Congressional criticisms of the program's slow rate of progress in previous years.

At the same time, the Russian Munitions Agency has had to fend off attacks on its budget from competing Russian government agencies. The RMA director reported to Nuclear Threat Initiative (NTI) officials recently that his colleagues from other ministries suggested that he does not need additional funding to support $\mathrm{CW}$ destruction since the G8 was going to take care of the problem. ${ }^{32}$

At a meeting between DoD CTR officials and Russian Ministry of Defense officials in 2000, a senior MOD official intimated that the CTR annual budget 
allocation for Russian nuclear warhead transportation and storage security was greater than the entire MOD Twelfth Main Directorate's warhead security budget. ${ }^{33}$ In fact, the CW elimination program approved by the Russian government in 2001 specifies that the Russian budget for this effort will be adjusted annually to reflect the volume of financial aid donated by state parties to the Chemical Weapons Convention. ${ }^{34}$ Furthermore, Russia's budget for the implementation of arms control agreements has fallen from $\$ 500$ million- $\$ 600$ million in $1996 / 1997$ to $\$ 60$ million-\$70 million in 1999/2000. ${ }^{35}$ NTI Vice President Laura Holgate stated at an October 2002 U.S. Senate Foreign Relations Committee hearing that this decline "reflects the degree to which Russia's threat reduction plans are currently being structured in anticipation of the other G8 nations meeting their $\$ 20$ billion pledge." ${ }^{36}$

The donor states under the G8 Global Partnership will also need to consider Russia's ability to absorb increased technical assistance. Many of the weapon elimination facilities in Russia are already operating at full capacity. In many of Russia's regions, a limited number of firms are capable of carrying out demilitarization work, and many are already engaged through existing programs. For example, in 1999, the U.S. DoD conducted project planning meetings with the Russian MOD's Twelfth Main Directorate in Moscow to estimate the costs of providing comprehensive security enhancements to Russian nuclear warhead storage sites. MOD introduced the DoD officials to a variety of local firms cleared to conduct the on-site work. However, MOD indicated that there was really only one security-cleared firm available in each region, each possessing limited personnel with adequate technical skills.

Many of the Russian ministries that are recipients of foreign nonproliferation aid have dedicated limited staffs to coordination efforts with their foreign partners. From the staff in the Russian Foreign Ministry who are authorized to negotiate nonproliferation implementing agreements, to the customs officials at the ports of entry where donated equipment will arrive, to the construction crews and technical personnel at the work sites, it is unclear whether Russia can handle a large increase in foreign assistance. To mitigate this potential bottleneck, it may be possible for new initiatives to leverage existing projects. For example, if the Europeans and Japanese were to engage Russia on the dismantlement of the general purpose submarines - as they have expressed a desire to doit might be advisable to utilize the U.S.-provided heavy equipment already in place to dismantle Russia's strategic missile submarines. In the spirit of the G8 Global Partnership, this type of coordination and burdensharing would extend the economies of scale for in-place assistance and sustain the service contracts currently enjoyed by Russia's shipyards.

\section{Analysis of Selected G8 Global Partnership Clauses}

The G8 Statement contains several opening paragraphs that frame the context and parameters of the initiative, followed by six principles and nine guidelines intended to facilitate implementation of the nonproliferation assistance programs. The first paragraph clearly references the threat of terrorism and the enhanced international cooperation catalyzed by the $9 / 11$ terrorist attacks as the driving force behind the establishment of the partnership. The second paragraph outlines the partnership's general goals and objectives, including a list of initial nonproliferation priorities in Russia and a specific reference to the debt-for-program financing option.

This section analyzes and comments on several of the key clauses and phrases contained in the statement. Many of these, as noted above, were drawn either directly from the U.S.-NIS Nunn-Lugar agreements, or from the common experiences of the G8 partners in previous and ongoing bilateral programs. In either case, the intent was to provide uniform standards and opportunities for both donor and recipient states. ${ }^{37}$

Principle 2: Develop and maintain appropriate effective measures to account for and secure such items ${ }^{38}$ in production, use, storage and domestic and international transport; provide assistance to states lacking sufficient resources to account for and secure these items.

Note the difference in the two clauses. While the United States is in the process of supporting the latter clause in Russia, it is somewhat surprising that Russia allowed the first clause to remain in the statement. Russian officials usually insist that WMD materials are adequately secured. It is certainly possible that Russia did object to the clause, but let it stand in return for a concession elsewhere. Of course, one way to read the first clause is that it is Russia's responsibility alone to develop and maintain a system of accounting. But given the context of this partnership, one could interpret the first clause to mean that there will be bi- or multilateral measures developed. This clause may be designed either to (1) provide President Putin with internationally agreed language that helps him acquire legislative approval from the 
Russian Federal Assembly for a warhead counting regime (or to support his efforts to meet the CWC and Biological Weapons Convention [BWC] provisions), or (2) encourage him to issue a presidential decree that carries sufficient legal weight.

Principles $4 \&$ 5: border controls versus export and transshipment controls

The former clause refers to technical assistance, such as guns, guard training, and X-ray machines. The latter phrase refers to legal and administrative arrangements and procedures. Russia requires assistance with both.

Guideline i. Mutually agreed effective monitoring, auditing and transparency measures and procedures will be required in order to ensure that cooperative activities meet agreed objectives (including irreversibility as necessary), to confirm work performance, to account for the funds expended and to provide for adequate access for donor representatives to work sites.

The phrases "auditing" and "account for the funds expended" can be traced directly back to the Nunn-Lugar umbrella agreements and specific "audit and examination" language included in all DoD CTR implementing agreements. This provision has worked well in CTR, for the most part, and remains an important element of the program. Not only does it provide assurances to the U.S. Congress that the assistance is being used for its intended purposes, but the audit trips also serve as a project management tool to perform such functions as observing the project's effectiveness and learning what items need maintenance.

In contrast, the phrases "monitoring," "transparency measures," and "adequate access for donor representatives to work sites" are new to this relationship. They are obviously intended to fill the holes that have caused so many problems with the existing programs. In particular, U.S. access to the work sites, or lack thereof, is a key driver of the success or failure of several core elements of DoD's Russian nuclear warhead security program and DOE's Material Protection, Control, and Accounting (MPC\&A) program.

It has become apparent that the only solution to the access/transparency issue is a legal one. Therefore, as with other clauses in the statement, it may be designed either to (1) provide President Putin with internationally agreed language that helps him gain legislative endorsement from the Russian Federal Assembly, perhaps through ratification approval, or (2) encourage him to issue a presidential decree that carries sufficient legal weight to resolve the transparency issue.
Guideline iii. Clearly defined milestones will be developed for each project, including the option of suspending or terminating a project if the milestones are not met.

The U.S. has had difficulty in the past defining exit criteria for contemplated or existing projects. Moreover, the United States has had bad experiences with Russia withdrawing promised support for construction projects, forcing the United States to add additional funding. Therefore, this clause possibly is meant to help the parties build credible exit criteria into new projects.

There is at least one challenge, though. Will the donor states be willing to endure the domestic political fallout of abandoning half-completed projects? Several large Nunn-Lugar projects evolved with Russian promises of substantial contributions. However, in every case, the Russian funding dissipated, leaving the U.S. with two options: double its assistance or walk away with nothing to show for tens - and even hundreds - of millions of dollars in sunk costs. In every case, the U.S. chose to increase its assistance.

For example, in 1992 and 1993 DoD entered into two agreements with Minatom to design and construct the Mayak Fissile Material Storage Facility. DoD and Minatom reached an understanding that each side would contribute roughly half of the total funding to construct the facility. In 1995, a comprehensive assessment estimated the total cost at $\$ 516$ million to complete a two-wing facility that could store 50,000 containers of fissile material. For a time, Vice President Gore and Prime Minister Chernomyrdin personally monitored progress on this project. However, after substantial U.S. investment and construction progress, Minatom announced that it would not be able to fulfill its half of the financial contribution. The United States nonetheless continued work on the project. The currently estimated U.S. cost to complete just the first wing, housing 25,000 containers, is approximately $\$ 388$ million. This amount would have been even higher were it not for the cost savings realized from the devaluation of the ruble following the 1998 financial crisis. ${ }^{39}$

Likewise, in accordance with a 1995 agreement, the initial plans to provide security enhancements to the Russian Ministry of Defense nuclear weapon storage sites were based on a sharing of resource contributions. At a meeting in 1996, the two sides concurred on an approach whereby DoD would procure the physical security equipment, and Russia would ship and install the equipment at its sensitive sites. As late as 1998, the DoD budget to purchase equipment for site security enhancements at 50 Russian national stockpile sites totaled approximately 
$\$ 225$ million. By 2001, that budget had increased to well over $\$ 600$ million for two reasons. First, MOD had added 73 operational-level warhead storage sites at Russian Air Force, Navy, and Strategic Rocket Forces bases to the list of sites to be upgraded. But more significantly, DoD had added shipping, site design, facility renovation and site preparation, and equipment installation to its budget. Since many of the operational-level storage sites may be closed under START I, they are scheduled to receive only the relatively inexpensive perimeter security systems and not the comprehensive security upgrades. Therefore, the bulk of the U.S. budget increase represents an assumption of originally Russian responsibilities. ${ }^{40}$

As these cases suggest, donor states participating in the G8 Global Partnership should be prepared to maintain funding control over the critical path parts of each project in order to ensure their eventual completion.

Guideline ix. Measures will be put in place to ensure effective protection of sensitive information and intellectual property.

Last year, the U.S. put in place a law that strengthens the government's ability to protect information provided by foreign governments and designated by the originating government as sensitive. ${ }^{41}$ In effect, the U.S. is legally bound to protect foreign government information at the classification level determined by the foreign government. $\mathrm{DoD}$ is using this law as the basis of a protocol with Minatom to exchange sensitive information. DoD has proposed to do the same with the Russian MOD, but MOD has intimated that it may prefer not to have a paper agreement.

In any case, the existence of the U.S. Freedom of Information Act (FOIA) concerns the Russians. The sharpest example is the declassification in the late-1990s of satellite imagery taken in the 1960s under the Corona program. The declassified imagery included hundreds of photos of Russian nuclear warhead storage sites. During several CTR program manager meetings, senior MOD officials strongly chastised $\mathrm{DoD}$ for this release, noting that the current sites are the same sites photographed thirty years prior. Essentially, Russia remains unconvinced that the United States will protect sensitive information that might be shared as part of cooperative nonproliferation projects. The declassified U.S. satellite imagery, for instance, released at a time when the United States was proposing that Russia provide greater information about the location and condition of its nuclear weapon storage sites, may have set back the CTR nuclear warhead storage security program by 2 to 3 years. Russian concerns will need to be addressed if projects requiring sharing of sensitive information are to move forward expeditiously.

\section{Ingredients for G8 Partnership Success}

All parties to the partnership should recognize that it will take a concerted effort to enhance the G8 initiative's prospects for large-scale success. This new partnership will help prevent proliferation both politically, by further integrating Russia into the international community, and functionally, by further eliminating excess WMD and missiles in Russia and the NIS.

The following outlines several measures necessary to ensure the success of the G8 Partnership. Based on the U.S. experience, the items listed below are intended to build on what has worked well and to mitigate what has worked less well. These recommendations are based on an assessment of the historical record of both U.S. and multilateral nonproliferation programs.

Individual projects should be bilateral. Discrete, niche projects that one donor country can fully fund under a well-defined, finite implementing agreement with a specific Russian recipient agency will have the greatest chance of successful implementation. As described elsewhere in this report, individual projects, negotiated by one donor and one recipient, and with focused objectives, have been historically simpler to negotiate and complete. Many of the partners, in fact, have bilateral projects either ongoing or planned. For example, the United States, Britain, and France all provided supercontainers designed to hold nuclear warheads inside railcars. The Russians avoided duplication — and the United States, Britain, and France coordinated among themselves-by requesting different sized containers from each donor. The French, for example, built containers much larger than the American version. Russia uses the French version to haul heavy warheads, presumably removed from SS-18 intercontinental ballistic missiles. As noted above, these types of projects were successful in part since each donor state undertook a discrete endeavor it could support that needed little multilateral coordination. It appears that this point remains fundamental to U.S. policy. As U.S. Under Secretary of State Bolton has noted, "We do not intend to establish a Global Partnership multilateral implementation mechanism or common fund. However, the G8 Senior Officials, as the coordinating mechanism, will address priorities, identify program gaps, and prevent duplication and overlap." ${ }^{42}$ However, according another State Department official who was involved in the negotiations to draft the G8 Statement, there will also be a 
concerted effort within the NSSG to develop collaborative, multilateral projects. ${ }^{43}$

Coordination by the NSSG should be authoritative but limited. The White House fact sheet on the G8 Global Partnership notes that, "The G8 will establish a senior-level mechanism to coordinate partnership activities, including monitoring progress and considering project priorities and opportunities." ${ }^{4}$ The G8 oversight body should limit itself (1) to ensuring adherence to the G8 Partnership principles, and (2) to prevent duplicative or counterproductive efforts. More specifically, the NSSG should be proactive. Partner representatives to the committee should actively acquire information on what their governments are doing and planning. It should also recognize the fact that different member countries will negotiate unique bilateral agreements with Russia and the other recipient states, due to the peculiar needs of each. However, the oversight body should strive to ensure that all agreements closely conform to the principles and guidelines, and that no bilateral agreement has detrimental affects on another member's bilateral agreement or negotiations. All donors should receive equal treatment, and Russia should receive equal treatment from all donors. The NSSG may facilitate this by helping to maintain consistent implementation policies among the G8 donors, as described below. Nonetheless, the NSSG should not be used as a tool to influence national nonproliferation strategies. Moreover, the G8 partners should resist any temptations to use the NSSG to micromanage specific bilateral or multilateral threat reduction projects. These actions would adversely affect the NSSG's effectiveness, add additional bureaucratic hurdles, and undermine the partnership's legitimacy among both the G7 donors and within Russia.

Russian consent ideally should be in the form of legislation approved by the Russian Federal Assembly, although a presidential decree may be sufficient. The Russian government should legitimize the threat reduction guidelines and principles so that they carry the weight of domestic law. This is the one action that the Russian Federation can take to uphold its commitment to cooperative threat reduction, which would require no Russian funding and would have the greatest positive effect. The donor states of the G8 should strive through diplomacy to achieve Russian legislative approval of the G8 principles and guidelines, although it may not be politically realistic. Perhaps the most the G8 can hope for is to use the principles as a baseline from which the sides can negotiate bilateral assistance agreements and protocols with Russia. However, on July 23, 2002, the Russian government issued Instruction Number KA-P4-10775, which specifies that the U.S.-Russian Nunn-Lugar umbrella agreement temporarily will be applied in full scope until Russia ratifies the 1999 protocol (which extended the agreement and provides for other provisions). This breakthrough may offer a precedent on which the G8 might build. As noted by U.S. Assistant Secretary of State for Nonproliferation John Wolf, "Unless Russia is prepared to implement the Guidelines, then this thing's going to be stillborn." ${ }^{45}$

Implementation policies among the G8 donors should be consistent. Perhaps through the limited oversight of the NNSG, Russian recipient agencies should be precluded from shopping for the best deal among the G8 donors. Past experience under the U.S. Nunn-Lugar program suggests that elements of the Russian government are adept at pursuing avenues most suitable to their own purposes. One programmatic area in particular has had enough overlap to be an issue: warhead security. Initially, this task fell strictly under DoD's CTR program. However, due to the perceived success of the DOE MPC\&A program with the Russian Navy and problems with certifying ${ }^{46}$ Russia to receive CTR assistance from DoD, DOE was able to expand its efforts to include Russian Navy warhead security enhancements. DOE's mission recently crept over to the Russian Strategic Rocket Forces, and there has been talk of DOE work at Russian Air Force sites. While most agree that it does not matter which U.S. agency - or even which country, for that matter-conducts the work, as long as the objectives are accomplished, these developments have caused bureaucratic turf battles and duplicative budgets. At the same time, one can hardly blame Russia for pursuing the avenue that will provide the most assistance with the least intrusiveness. This example is not intended as a call for the G8 to coordinate within countries and not just between them. Rather, it is meant to warn of the difficulties of effective oversight and the dangers of not carefully delineating responsibilities.

The U.S. needs to exercise leadership. The European states and Japan, at times, have requested that the United States suggest areas where they could provide threat reduction assistance and have requested the U.S. government's concurrence on plans developed with anticipated NIS recipients. Examples cited above include: the procurement of warhead supercontainers, the construction of the Mayak FMSF, the construction of the Shchuch'ye CWDF, and the science and technology 
centers. Some discrete projects, such as British and Scandinavian efforts to deal with the radioactive contamination on Russia's Kola Peninsula, are possible without multilateral interaction. Experience indicates, however, that many projects will require U.S. leadership as the partner with the largest and most comprehensive cooperative nonproliferation program.

EU, Canadian, and Japanese assistance should complete the puzzle. The G8 partners should use the newly committed European, Canadian, and Japanese funding to complement the existing U.S. Nunn-Lugar program. For example, Germany's support for the retraining and resettlement of Soviet military personnel stationed in the former East Germany filled a gap long desired by Russia, but which went unfulfilled by Nunn-Lugar assistance due to restrictions imposed by the U.S. Congress. One important area for future coordinated G8 support entails European, Canadian, and Japanese funding for the operations and maintenance of projects initiated or completed under U.S. funding. While such efforts may not generate the positive publicity of initiating new projects, ensuring ongoing operations and maintenance support may be the best way to sustain the concrete successes of the NunnLugar programs.

EU, Canadian, and Japanese assistance should also expand the puzzle. The G8 partners should use the newly committed European, Canadian, and Japanese funding to supplement the existing U.S. Nunn-Lugar program by providing assistance for areas into which the U.S. is either unwilling or unable to expand. In this context, Partnership monies might in particular be leveraged for projects of direct concern to the Europeans and Japanese, such as dismantling tactical nuclear weapon delivery systems and nuclear-powered attack submarines. By expanding the types of projects to be addressed, the G8 Global Partnership will enhance its impact on the universe of proliferation threats.

NATO-derived standardization processes should be applied. The U.S. and its NATO partners have longestablished procedures to coordinate multilateral weapon and communication system design, development, testing, and acquisition. Of the G7 countries-the United States, Britain, Canada, France, Germany, Italy, and Japan-only Japan is not a member of NATO. By applying these procedures to standardize equipment assistance destined for Russia, NATO-derived processes can lead the G8 away from the problems encountered by the emergency response program described above and toward a more consistent overall threat reduction effort. Without some effort to standardize equipment and procedures, local and regional guard forces for WMD-related facilities in Russia may receive radios that will not communicate with each other, various Russian agencies may receive proliferation response training containing procedural conflicts, or facilities may be built in Russia that receive incompatible equipment from different donor partners. NATO-derived standardization skills may be most effectively applied within the NSSG. However, the NATO members of the G8 should take care to utilize the multilateral program management skills developed through its NATO experience and avoid giving the impression that the G8 Partnership is a NATO program.

\section{Conclusions}

The multilateralization of the Nunn-Lugar cooperative security model is an important and significant step in the global effort to reduce the threat of WMD proliferation. By forming the G8 Global Partnership, the G8 members have committed to sustaining and expanding the effort led by the U.S. since 1991. While the terrorist attacks on the United States on September 11, 2001, played a significant role in altering both the U.S.-Russian relationship and the state of global affairs, the event should not be overemphasized in the nonproliferation effort. This is a long-term challenge that requires comprehensive and sustained solutions. Each of the partners, including Russia, must do its part to make the G8 initiative a success.

Even where few policy barriers exist, practical matters often disrupt efficient project management. In particular, tax and liability exemptions frequently prompt international disputes and project delays. It is entirely possible that President Putin will use the G8 Statement as a basis for gaining legislative endorsement of the cooperative threat reduction effort. By obtaining Federal Assembly approval of the U.S.-Russia umbrella agreement, or perhaps by writing a new law that covers all G8 Partnership programs, Russia would eliminate substantial roadblocks to effective and efficient implementation. While not glamorous, it is one of the most important concrete steps Russia can contribute to the cooperative effort.

By the next G8 Summit at the beginning of June 2003 in Evian, France, the United States will press its European, Canadian, and Japanese Partners to commit their half of the $\$ 20$ billion goal. ${ }^{47}$ As NTI Vice President Holgate told the U.S. Senate in October 2002: 
We have seen some early initiative from G8 nations to honor their pledges, but all member nations have much more to do to meet the high expectations they created with their bold statements at Kananaskis. G8 nations have given themselves and the world a fleeting opportunity to truly transform threat reduction efforts. The stability of a $\$ 20$ billion commitment over the next decade creates an entirely new fiscal environment for such activities, and the multilateral nature of the "Global Partnership" affords new opportunities for collaboration and synergy, in which the whole really is greater than the sum of its parts. ${ }^{48}$

One of the often overlooked intangible benefits of threat reduction cooperation is the relationship-building that occurs among professional military officers, among professional bureaucrats, between scientific communities, and across the industrial and private sectors. Too often, managers, decision makers, and legislators in the threat reduction cooperation business focus exclusively on the scorecard of dismantled weapon systems. Equally important are the day-to-day working relationships that develop between participants, who learn how the other side thinks, come to understand why the other side conducts business in particular ways, and gain insight into the decisionmaking processes of the partners. As opposed to formal arms control treaties, which are concluded through distant and diplomatic means under the presumption of an adversarial relationship, threat reduction cooperation requires on-the-ground engagement. Bureaucrats, military officers, scientists, and business employees work together to solve security objectives. Progress is then made through a collaborative learning process. These exchanges effect cultural stereotypes on both sides and build another level of trust and understanding among influential experts. ${ }^{49}$

Each current and future state party to the G8 Global Partnership shares the nonproliferation commitment. At the same time, each state party brings a unique perspective and set of experiences to the group. Americans, Europeans, Canadians, and Japanese may wish to focus on different aspects of the proliferation problem, and each will be in a distinct geographical, political, and financial position to do so. Russians will have their own priorities, which should be considered and respected. It seems unlikely that the general goals and objectives that each partner brings, though, will be contradictory. It will therefore be incumbent on the G8 as the coordinating body to ensure that the projects selected for implementation are complementary, are mutually beneficial, and enhance the nonproliferation objective.
${ }^{1}$ Acknowledgements: Some of the material contained in this report was developed originally under the auspices of the Center for International and Security Studies in the School of Public Affairs at the University of Maryland and supported by a grant from the John D. and Catherine T. MacArthur Foundation. In that context, I thank Professor John Steinbruner and Dr. Nancy Gallagher for their encouragement and insights. I also thank Dave Jackson, Lewis Dunn, Richard Soll, Steve Bauer, and the editorial team at Science Applications International Corporation for their input and guidance on a version of this report intended for one of our customers. The information in this report does not represent, and may not coincide with official U.S. government policy, nor does it represent the positions of the University of Maryland, the Center for International and Security Studies at Maryland, Science Applications International Corporation, or any other organization with which the author may be affiliated. The information in this report, including the policies described and the recommendations offeredincluding any mistakes - are strictly the author's.

${ }^{2}$ For the full text, see Statement by G8 Leaders, "The G8 Global Partnership Against Weapons and Materials of Mass Destruction," Kananaskis, Canada, June 10, 2002, <http://www.g8.gc.ca/kananaskis/globpart-en.asp>.

${ }^{3}$ This article will use the term Nunn-Lugar to describe the full range of threat reduction cooperation programs undertaken by the U.S. government in the NIS. Often called Cooperative Threat Reduction (CTR), this latter name is more accurately applied to the Department of Defense (DoD) element of the overall program. The use of Nunn-Lugar more readily captures all elements of the threat reduction programs, including those managed by the Departments of Commerce, Energy, and State.

${ }^{4}$ U.S. State Department official (name withheld by request), interview by author, Washington, DC, August 15, 2002.

${ }^{5}$ U.S. Senate, Committee on Foreign Relations, "Testimony of John R. Bolton, Under Secretary of State for Arms Control and International Security on the G8 Global Partnership," 107th Congress, 2nd Session, October 9, 2002, p. 6.

${ }^{6}$ Statement by G8 Leaders, "The G8 Global Partnership."

${ }^{7}$ U.S. State Department official (name withheld by request), interview by author, Washington, DC, August 12, 2002.

${ }^{8}$ Ibid.

${ }^{9}$ Mara D. Bellaby, "Some Russians Skeptical of G-8 Plan," AP, June 28, 2002.

${ }^{10}$ EU Council Joint Action 1999/878/CFSP.

${ }^{11}$ European Commission, "Russian Federation Country Strategy Paper 2002. 2006," Brussels, Belgium, December 27, 2001.

${ }^{12}$ Frida Blom, Nuclear Disarmament and Non-proliferation Assistance to Russia, (Stockholm: Swedish Peace and Arbitration Society, November 2001), p. 25.

${ }^{13}$ A more extensive description of these projects is available on the European Commission's web site: http://europa.eu.int/index_en.htm.

${ }^{14}$ Official Journal of the European Communities, L 180/2, July 3, 2001.

${ }^{15}$ Bulletin EU 4-1996, Moscow Nuclear Safety and Security Summit Declaration.

${ }^{16}$ U.S. Senate, Committee on Foreign Relations, "Testimony of John R. Bolton," p. 8.

${ }^{17}$ The Russia Munitions Agency recently published extensive information on the Russian CW arsenal at-_<http://www.munition.gov.ru/> .

${ }^{18}$ For additional information, see (1) U.S. General Accounting Office, "Weapons of Mass Destruction: Efforts to Reduce Russian Arsenals May Cost More, Achieve Less Than Planned," GAO/NSIAD-99-76, April 1999; (2) U.S. National Defense Authorization Act for FY 2001, Public Law 106-368, Section 1309 - Chemical Weapons Destruction; and, (3) National Defense Authorization Act for FY 2002, Public Law 107-107, Section 1309 - Chemical Weapons Destruction.

${ }^{19}$ Russian Munitions Agency, "On completion of construction of the first starting complex of Russian facility

for destruction of chemical weapons," August 22, 2002, <http:// www.munition.gov.ru/eng/press.html>.

${ }^{20}$ For additional information, see: http://www.istc.ru/.

${ }^{21}$ For background information on the ISTC, visit its web site, $<$ http:// www.istc.ru>. For similar information on the STCU, see $<$ http:// www.stcu.kiev.ua>.

${ }^{22}$ For a description of problems encountered during the early years of the ISTC, see Ildar A. Akhtamzian, "The International Science and Technology Center: Bureaucratic Games," Nonproliferation Review 3 (Fall 1995), pp. 79-83.

${ }^{23}$ For a discussion of the ISTC and STCU, see Scott Parrish and Tamara Robinson, "Efforts to Strengthen Export Controls and Combat Illicit Trafficking and Brain Drain," Nonproliferation Review 7 (Spring 2000), pp. 120-21. 
${ }^{24}$ For the full text, see: U.S. Department of State, "U.S.-Russian Treaty on Strategic Offensive Reductions," May 24, 2002,<http://usinfo.state.gov/topical/ $\mathrm{pol} / \mathrm{arms} / 02052441 . \mathrm{htm}>$.

${ }^{25}$ Richard A. Lugar, "A Tool for the New U.S.-Russian Strategic Relationship," Speech to the Carnegie International Nonproliferation Conference, Washington, DC, June 19, 2001.

${ }^{26}$ Nuclear Threat Reduction Campaign, "Issue Paper: Issue Paper: Implementing a Debt Reduction-For-Nonproliferation Program with Russia: Re-directing Debt Repayment to Fund Crucial Non-Proliferation Priorities," April 3, 2002, $<$ http://justice.policy.net/ntrc/index.vtml $>$.

27 "Russian foreign state debt expected to reach $\$ 124.5$ billion in 2003," Interfax, August 28, 2002; "Russia Faces Foreign Debt Payments," AP, August 25, 2002.

28 "Russia Faces Foreign Debt Payments," AP, August 25, 2002.

29 "Russia Faces Foreign Debt Payments," AP, August 25, 2002.

${ }^{30}$ Incidentally, this issue is one of Senator Lugar's "Top Ten" priorities for CTR. See: http://lugar.senate.gov/nunnlugar.htm\# topten.

${ }^{31}$ U.S. Senate, Committee on Foreign Relations, "Testimony of John R. Bolton," p. 8.

${ }^{32}$ U.S. Senate, Committee on Foreign Relations, "Testimony of Laura S.H. Holgate, Vice President for Russia/New Independent States, Nuclear Threat Initiative, on the G8 Global Partnership," 107th Congress, 2nd Session, October 9, 2002 , p. 6.

${ }^{33}$ The author was a participant in these meetings.

${ }^{34}$ Russian Munitions Agency, "The Federal Special Program: Chemical Weapons Destruction in the Russian Federation," in PIR Center, "Foreign Programs Reducing Russia's WMD Threats: Appraisal and Outlook," a report for the CSIS project, Strengthening Cooperative Threat Reduction with Russia: A U.S.-European Initiative, Moscow, unpublished paper, April 15, 2002, p. 88.

${ }^{35}$ Stockholm International Peace Research Institute, Yearbook 2000: Armaments, Disarmament and International Security, (Oxford: Oxford University Press, 2001), p. 314 .

${ }^{36}$ U.S. Senate, Committee on Foreign Relations, "Testimony of Laura S.H. Holgate," p. 6.

${ }^{37}$ It will be clear to the reader that some of the following commentary is based on the author's seven years of experience working on the U.S. Nunn-Lugar program. 38 "Such items" refers to nuclear, chemical, radiological and biological weapons; missiles; and related materials, equipment and technology.

${ }^{39}$ Funding figures and assumptions are based on the author's personal experience with the CTR program.
${ }^{40}$ Ibid..

${ }^{41}$ Public Law 106-398 [H.R. 4205], October 30, 2000. Based on the provisions of Section 1073 of H.R. 5408, introduced October 6, 2000. This law amends Chapter 3 of Title 10, United States Code by adding a new Section 130C.

${ }^{42}$ U.S. Senate, Committee on Foreign Relations, "Testimony of John R. Bolton," p. 10.

${ }^{43}$ U.S. State Department official (name withheld by request), interview by author, Washington, DC, August 15, 2002.

${ }^{44}$ The White House Office of the Press Secretary, "Fact Sheet: G-8 SummitPreventing the Proliferation of Weapons of Mass Destruction" Kananaskis, Canada, June 27, 2002, <http://www.whitehouse.gov/news/releases/2002/06/200206277.html>.

45 "John Wolf Interview: Details on G-8 Global Partnership Against the Spread of WMD," Center for Nonproliferation Studies, Monterey Institute of International Studies, August 28, 2002, < http://cns.miis.edu/pubs/week/020909.htm.>

${ }^{46}$ Each year, U.S. Nunn-Lugar legislation requires that the president certify that each recipient state is conducting itself as a good citizen of the world. Two of the key criteria stipulate that each recipient state is committed to meeting its international arms control treaty obligations and abiding by human rights norms. The responsibility for issuing the certifications is carried out by the U.S. State Department, in consultation with other government agencies. Interestingly, those particular certification requirements are specific to the Nunn-Lugar authorizing legislation for the Departments of Defense, State, Commerce, and others; no such requirements are imposed on the DOE element of the program. In January 2002, the State Department decided that it could not certify Russia for fiscal year 2002, primarily due to concerns about Russia's biological weapons activities and possible lack of commitment to the international BW control regime. Congress provided the president with a certification waiver - on the basis of national security - late in the 2002 fiscal year, but it expired on October 1 when fiscal year 2003 started. Congress is in the process of issuing the president additional certification waivers, but this issue is likely to continue to constrain significant elements of the U.S. Nunn-Lugar program.

${ }^{47}$ U.S. Senate, Committee on Foreign Relations, "Testimony of John R. Bolton," p. 9 .

${ }^{48}$ U.S. Senate, Committee on Foreign Relations, "Testimony of Laura S.H. Holgate," p. 1.

${ }^{49}$ Charles L. Thornton, "Toward a General Model for International Cooperative Threat Reduction," paper presented at the Annual Conference of ISA-South/ ISSS/ISAC, Richmond, VA, October 18-20, 2002, p. 21. 